Available Online at https://journal.unismuh.ac.id/index.php/otoritas

Otoritas : Jurnal Ilmu Pemerintahan, 11 (1), April 2021, 54-62

\title{
A Commitment to Public Office Ethics Reduces the Administrative Corruption Manifestation in Sudan
}

\author{
Zuly Qodir $^{1 *}$, Adil Hasan Ibrahim ${ }^{1}$ \\ ${ }^{1}$ Master of Government Affair and Administration, Postgraduate Program, Universitas Muhammadi- \\ yah Yogyakarta. Jl. Brawijaya Tamantirto, Kasihan, Bantul, 55183, Yogyakarta, Indonesia.
}

Received: 22 June 2020; Revised: 16 February 2021; Accepted: 27 April 2021

\begin{abstract}
This paper dealt with the issue of a commitment to the public office ethics reduces the administrative corruption manifestations in Sudan. The purpose of this paper is to find out what are the administrative corruption manifestations and how the commitment to the public office ethics contributes in the decreasing of administrative corruption forms. This paper depends on the literature review and uses descriptive approach in order to describe the forms of corruption which are related to the administration. Qualitative method has been followed in this work because, according to the view of the researcher, it is acceptable for this kind of study. The findings show that, embezzlement, extortion, exploitation of public position, forgery, deception, mediation, nepotism, favouritism and gifts to the public office are all shapes of administrative corruption that are pervasive in Sudan, Also, it indicates that, high levels of corporate transparency (auditing and reporting) and high Internet access can be beneficial in Sudan, that by combating corruption in the public sector and adopting effective policies to encourage the development of the private sector. Likewise, increase of salaries and wages for public sector workers can contribute in corruption reduction. The study recommends strongly to implement the principles of ethics of public offices, and law should be set in order to organize the bad morals of individuals in government agencies in Sudan.
\end{abstract}

Keywords: Public Ethics; Public Service; Corruption; manifestations; Sudan

How to Cite: Qodir, Z., \& Ibrahim, A. H. (2021). A Commitment to Public Office Ethics Reduces the Administrative Corruption Manifestation in Sudan. Otoritas : Jurnal Ilmu Pemerintahan, 11(1), 54-62.

Permalink/DOI: https://doi.org/10.26618/ojip.v11i1.3590

${ }^{*}$ Corresponding Author.

E-Mail : zuly_qodir@yahoo.com

Copyright (C) 2021, Otoritas : Jurnal Ilmu Pemerintahan, ISSN: 2088-3706 (Print), ISSN: 2502-9320 (Online) 


\section{INTRODUCTION}

People assume in the public employee the desire for positive behaviour in the field of service in public job, and his respect for himself and others from colleagues in the public office on the one hand, and for auditors of the public institution on the other. People also assume that the public employee prevails the public interest over the personal interest while preserving job interests and employee rights (Saban, Basalamah, Gani, \& Rahman, 2020).

All common forms and images of corruption result from deviant actions of public officials, individually and collectively. Employees are workers of the administrative authority, and all moral or legal personalities by their nature, such as the state and other administrative factors of the public, cannot fulfil their mission and achieve their goals except through the people who express their will and they are public officials. Based on this, it can basically build that the public employee plays a pivotal role in the seed of corruption and its spread in the government apparatus sector (Taboli, Samieé, Ehsani, 2019).

Public service professionalism is a critical part of public servants ' day-today practices. There is no room other than to operate with complete transparency. Ethics includes fairness, transparency, dignity, empathy and the understanding of the difference between right and wrong. It involves the strict working of entities with legislation (Chapman, 2019). The public service's general purpose is to satisfy the government's mission, that is, to save and grow people through the implementation of policy policies. The Public Service is accountable for the public official who makes, and executes public policy actions that explicitly or indirectly impact citizens 'interests and wellbeing essentially their roles, expertise, abilities, competences, and moral principles. Public officials may take actions about various valuables for the community and the organisations in their entirety in order to perform their regular duties. They use their social and ethical principles when making these judgments (Yusuph, Guohua, \& Abeid, 2017).

A huge of work has done in the field of ethics in different views, as (Yusuph et al., 2017) argued about the conducts in public services and codes of ethics, their study aim was examining the role of codes of ethics and conducts of public services in effecting public administrator's decision making in ethical situation of dilemma. Study found that conducts and codes of ethics both of them influence the decision making by public administration in ethical dilemmas solutions. Additionally, (Duraku, 2018) discussed the ethics of public administration, his study came up with the eight main components of ethics infrastructure, namely, legal effective framework, political adherence, mechanisms of political accountability, conduct workable codes, socialization professional mechanisms, effective efficiency civil society, cheaper public services and body of central ethics coordinating.

Also, Heckler \& Ronquillo (2020) conducted a research on the ethical dilemmas in entrepreneur organizations, Their paper argues that the classical debate on deontology and teleology can offer a useful conceptualization of ethics. their study showed that social enterprise organizations (SEO) managers who have access to multiple ethical sources create greater confidence in future resolutions and are therefore able to devote more resources to mission-oriented results. Moreover, (Abdullah, Sulong, \& Said, 2014) discussed the ethical judgement and ethical climate on the public servants in Malesia, the aim of his study was analysing the impact of ethical judgements on the intention to the unethical behaviours among the public servant in Malesia, however, his study came out gave evidence of 
that, there is a harmony between ethical judgement and ethical climate of the public servant.

Likewise, Calderón-orellana \& Araya -bugueño, (2019) undertook a study, the aim of their research was to analyse the codes of ethics in the government institutions measuring by the principles of good government, that represent in transparency, accountability morality, responsibility. Their study gave a strong evidence that, the principles of smart government are not clearly or directly integrated into codes. Furthermore, Osmani \& Bashi (2014) has come with the ethics in public administration that reduce or curbs some phenomenon of corruption such as theft, bribery, embezzlement, nepotism and kickback. He mentioned that, the main factor which affect the conceptualization of the civil servants is the political environment, how do political situations effect the performance of labours inside a particular entity.

In addition to that, Chapman (2003) argued the accountability and ethics in public services, he said that, ethics in liberal democracies is about the implementation of standards of moral by the people's representatives and by the employees in government agencies, institutions and entities. His study aims are; to draw attention to political systems aspects in the context of ethical behaviour, to treat with the aspects of the systems of the administrations and he also wanted to discover the relation between the administrative and political systems in the framework of the implementation of the concept of accountability. Adding to that, Ferreira, Castro, \& Lopes (2019) have discussed the question; Does corruption in public sector corporate ethics ? their findings showed that corruption in the public sector has an important and detrimental effect on the ethical actions of businesses.

Findings on corporate ethics may cover quality control, corporate transparency and Internet use. This means that fighting public corruption, encouraging the development of market-friendly regulation, improving audit and reporting standards and through the scanning degree of a country will boost corporations ' ethical behaviour. After reviewing the previous studies, it was found that, this study is unique by addressing the issue of corruption and a commitment to the public office ethics in Sudan, the purpose of this study is to attempt to understand corruption manifestations in Sudan and how a commitment to public office ethics reduces corruption.

\section{RESEARCH METHODS}

This paper depends on literature review and it uses descriptive approach, to descript how the adherence to the public office ethics reduce the corruption manifestations in public sector, the writer chose this qualitative method because it is an appropriate method for this work according to the point-view of the researcher. Data and information for this paper have been collected from different sources particularly secondary data sources which involves; books, scientific papers, reports, newspapers, and other documents that are relevant to the study. The journals and articles that used in this research have collected from very recognized publishers such as Emerald insight, Google scholar, IEEExplore, academia.edu, Springer link, Science Direct, Web of the science core collection, ACM digital library, and Libgen Iceland. All the journals are peer-reviewed.

\section{RESULTS AND DISCUSSION}

\section{Manifestations of Grand Corruption in Sudan}

Corruption is the misuse of power, it involves the behaviour of employees or officeholders in public and private sectors, these behaviours are unlawful, and improper. Corruption in its different forms take two types (1) petty: this type 
Available Online at https://journal.unismuh.ac.id/index.php/otoritas

Otoritas : Jurnal Ilmu Pemerintahan, 11 (1), April 2021, 57

of corruption includes (small scale, low level, bureaucratic or administrative). (2) grand corruption: this sort of corruption is called (elite, high level, political) it involves, briberies, embezzlements, theft, fraud, favouritism, kickbacks and facilitation payments (Hope, 2020).

Corruption was described as a cancer, as a greatest eroding factor in a community, it was portrayed as a diseases to assert that, it is a universal phenomenon (Pertiwi \& Ainsworth, 2020). In Sudan corruption can be available in all sectors of the economy and at the all classes of the country apparatus. Corruption pervasive in Sudan in various shapes such as political corruption, financial corruption and, nepotisms (Martini, 2012).

Today, Sudan is number 173 in ranking of the corruption perceptions in the world, out of 180 countries in 2019. There are various types of administrative corruption manifestations in Sudan, such as; bribery, embezzlement, extortion, exploitation of public position, forgery, deception, mediation, nepotism, favouritism, gifts to the public office and taxation escape. Due to the several forms of administrative corruption manifestations, the researcher chose, three forms which are larger spread. Figure 1 shows the ranking of Sudan in corruption perception index, according to transparency international organization report from 2010 to 2019.

Bribery

Bribery is one of the most common patterns of administrative corruption, it has become a serious social disease in most of the societies and in developing countries in particular, this phenomenon is growing due to the absence of supervision and the absence of the rule of law. The widespread phenomenon of bribery has negative effects, which are reflected in moral and job value (Quah, 2017).

In Sudan, it seems that non-official payments are the only way to create a business. Average residents do not appear to offer decent public facilities without a donation or bribery. The Transparency International Global Corruption Barometer of 2016 reports that 48 percent of the Sudanese polled over the last 12 months say they had charged a bribe.

Elamin (2019) mentioned three tools to reduce manifestations of corruption in Sudan, they are; punishment, prevention and education. As this approach was implemented in Hong Kong; punishment is based on setting very restrictive new laws for the offences such as theft, bribery, embezzlement, blackmail, deception, a false accusations and obstruction of justice (Elamin, 2019).

Corruption in the delivery of public

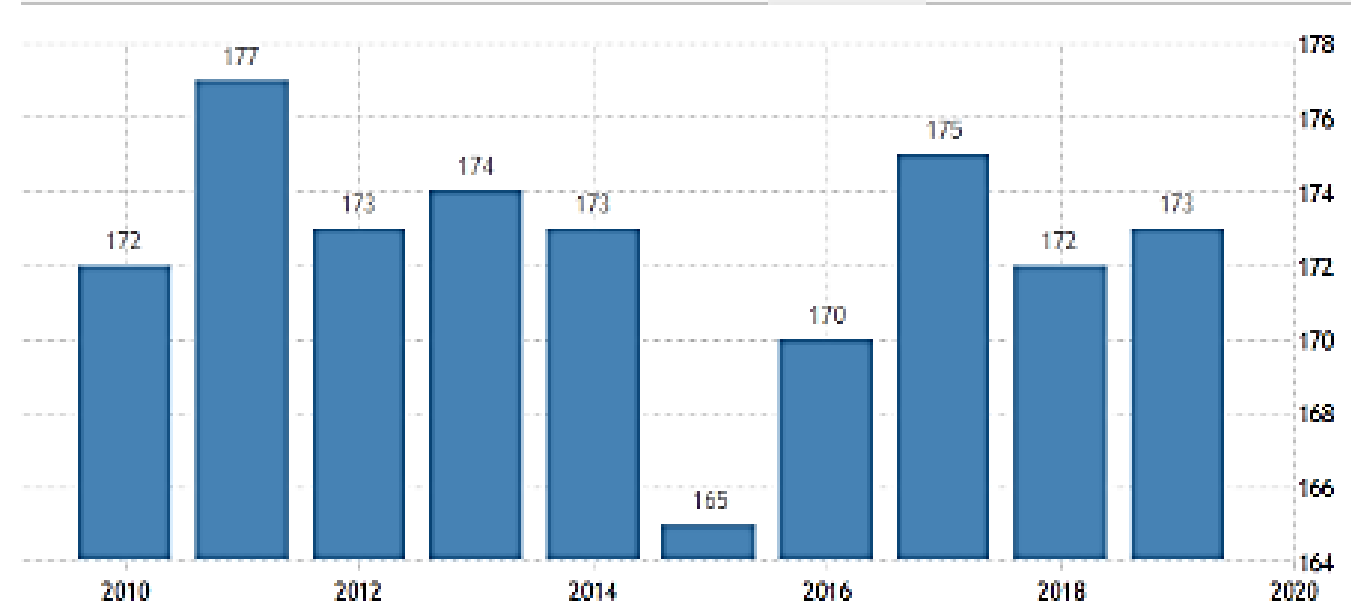

Figure 1. Corruption Perception Index of Sudan Source: tradingeconomics.com (2020) 
facilities in Sudan poses a very large risk for businesses. As far as the public services are concerned, two out of ten businesses surveyed plan to receive contributions for electricity power connections and one out of 10 for water. Bribes to operational authorisations or total facilitation fees are less frequent, but still a possibility. In general, abuse in the public sector is perceived by the majority of Sudanese people. Half of the people surveyed record bribery encounters in 2015 as they provide public services. In general, it is exceedingly burdensome, slow and difficult for businesses to receive licenses, operating permits or related demands (Anticorruption, 2020).There for, respecting the law as public office ethics reduces the administrative corruption manifestations.

\section{Embezzlement}

The table 1 illustrates the amounts of money stollen by Sudanese government organizations since 2000-2007. As a result of the liquidation of the institutions in Sudan by the ex-regime, the federal state ministries and governmental institutions have established their own departments and expelled the people of competence and efficiency.

Favouritism and embezzlement have spread in the institutions of government in the era of ex-regime. Public agencies have become fiefdoms, officials handle and manage those institutions as they want. It is not surprising that Sudan comes second in corruption after Iraq in the world Al-Arabi ranked (129) for the most corrupt countries - within (145) countries according to the Global Corruption Index issued by Transparency International, number of the pages of newspapers were filled with corruption issues of Sudan. Embezzlement increased in public and private institutions in Sudan, where the reports of the Auditor General indicate that the looted amounts are estimated in 2003 at (396) million dinars, while they amounted to (168) million dinars in

Table 1. Money Stollen in Public Institutions of Sudan

Source: Processed by the Authors (2020)

\begin{tabular}{|c|c|c|c|c|c|}
\hline Fiscal Year & $\begin{array}{l}\text { Amounts } \\
\text { of Funds } \\
\text { Stolen in } \\
\text { SUD } \\
\text { millions }\end{array}$ & $\begin{array}{l}\text { Amounts and \% } \\
\text { in Central } \\
\text { Government } \\
\text { Organizations } \\
\text { in Khartoum }\end{array}$ & $\begin{array}{l}\text { Amounts and \% } \\
\text { in Central } \\
\text { Government } \\
\text { Organizations in } \\
\text { States }\end{array}$ & $\begin{array}{l}\text { Amounts } \\
\text { and } \% \text { in } \\
\text { Public } \\
\text { Companies }\end{array}$ & $\begin{array}{c}\text { Amounts and } \\
\% \text { Stolen from } \\
\text { Zakat }\end{array}$ \\
\hline $2000-2001(1)$ & 278.7 & $\begin{array}{r}54 \\
19 \%\end{array}$ & $\begin{array}{r}16 \\
6 \%\end{array}$ & $\begin{array}{r}199 \\
71 \%\end{array}$ & $\begin{array}{r}10 \\
4 \%\end{array}$ \\
\hline $2001-2002(2)$ & 267.9 & $\begin{array}{r}113.8 \\
43 \%\end{array}$ & $\begin{array}{r}19.7 \\
7 \%\end{array}$ & $\begin{array}{r}103.9 \\
39 \%\end{array}$ & $\begin{array}{l}30.5 \\
11 \%\end{array}$ \\
\hline $2002-2003(3)$ & 168.2 & $\begin{array}{l}21.1 \\
13 \%\end{array}$ & $\begin{array}{l}21.7 \\
13 \%\end{array}$ & $\begin{array}{r}125.4 \\
74 \%\end{array}$ & - \\
\hline $2003-2004(4)$ & 396 & $\begin{array}{l}60.9 \\
15 \%\end{array}$ & $\begin{array}{l}62.8 \\
16 \%\end{array}$ & $\begin{array}{r}273 \\
69 \%\end{array}$ & - \\
\hline $2004-2005(5)$ & 542.5 & $\begin{array}{l}63.5 \\
12 \%\end{array}$ & $\begin{array}{r}124.8 \\
23 \%\end{array}$ & $\begin{array}{r}354.2 \\
65 \%\end{array}$ & - \\
\hline $2005-2006(6)$ & 904.3 & $\begin{array}{r}69.3 \\
8 \%\end{array}$ & $\begin{array}{r}164.1 \\
18 \%\end{array}$ & $\begin{array}{r}670.9 \\
74 \%\end{array}$ & - \\
\hline $2006-2007(7)$ & 561.2 & $\begin{array}{r}280.6 \\
50 \% \\
\end{array}$ & * & * & - \\
\hline
\end{tabular}


2002, and this means a steady escalation in embezzlement (Elamin, 2019).

According to our investigation showed that The report of the Auditor General of the State of Khartoum in 2014 August 2015 revealed an increase in public money crimes, as the total number of cases of crimes of public money and financial irregularities amounted to (29) million and (459) thousand and (136) pounds and (57) piasters. The previous numbers of money are in Dinar currency, which was issued in 1992 up to 2007.

Whereas the report of auditor general is written in pounds, which issued in 2007 up to today. Likewise, Ismail (2017) stated that, the Sudanese Transparency Organization revealed that the losses of the public money due to corruption in the country exceeded $\$ 18$ billion annually, that take places because of the absence of financial oversight and weak regulatory laws contributed to the spread of the phenomenon of corruption.

One of the investigators said that, "Our politicians don't follow what they teach, they tell one thing and completely opposite stuff, they want to remain in place as long as they can". Regardless of a political problem, inequality persists. Therefore, we have to start at the top in order to fight corruption. Only those in positions of leadership who can set examples and principles of integrity, duty, openness, accountability and fear of God (Ismail, 2011). The researcher adding that, if the offices are adherent to the ethics of public positions such as selfintegrity, the corruption will reduce or will be curbed, because self-integrity means to be honest and trusted.

\section{Forgery}

In Sudan, there has been increasing in the crime of forgery, which is considered one of the serious and threatening crimes to society, which carries a sentence of imprisonment of 7 years. most of the counterfeiting crimes are spearhead- ed by Groups that specialize in the arts of forgery using the latest technology, such as inks, seals, trousses, and signatures, so that their documents appear at their best. For instance; an employee of the Sudanese Electricity Company forged two bills to purchase electricity, one of them belonging to the Sudanese Company for Communications, Zain, where the value of the two bills reached 24 thousand pounds and he did not supply them to the Electricity Ministry. During the review, the forgery crime was revealed, so that the employee was arrested. In investigations he stated that he was able to obtain the bill from the electricity system, then modified the bill and sold it to another person.

Two examples clarify the forgery and its punishment (1) Sudan's criminal law punishes the manufacture and falsification of seals and official marks (Article 120), it says; whoever makes, fakes or possesses any official logo, mark, or seal from the seals of the state or persons with the intention of using any of that in committing a forgery, shall be punished by imprisonment for a period not exceeding five years and may be punished with a fine. (2) The penalty for forgery in documents (Article 123): whoever commits the crime of forgery in documents or uses or delivers a false document for the purpose of using it, knowing that the document is forged, he shall be punished with imprisonment for a period not exceeding five years, and he may be punished with a fine. He may be punished with a fine. If the public offices implement the ethics of public servants, the rate of forgery and other forms of corruption will be reduced.

To reduce corruption in Sudan, several steps can be taken, representing judiciary independency, implementation of rule of law, accuracy censorship of public expenditures and of the state budget application, the establishment of effective independent anti-corruption commissions, the adoption strict anti-corruption legislation, well implementation of anti- 
corruption legislation, unlimited freedom of the press and more investigative journalism, the emergence of watch-dogs institution and, a commitment to codes of ethics or codes of conduct for public officials of Sudan.

A book written by Kafi (2018), reviewed an important experiences of anticorruption in countries were suffered the corruption (1) Singapore: Singapore was very corrupted country. Today, Singapore ranks third $(3 / 180)$ in the ranking of the Corruption Perceptions Index, its score is 85/100.

Singapore has succeeded in fighting corruption by Reducing the number of laws, rules and procedures, the state clarified all the procedures that the citizen follows in obtaining service in government institutions, as well as the state has raised the salaries and wages of all employees of state institutions so that they do not do corruption due to poor salaries, and the minister's salary in Singapore is the highest in the world. In any attempt to do corruption, the employee or minister is dismissed and is prohibited from obtaining any other job in the state of Singapore.

Apart from Singapore, we can see the situation in Hong Kong. There were many cases of corruption in Hong Kong, but the state has curbed and reduced the corruption. Today its ranked (11/180), whereas its score in corruption perception index is $(77 / 100)$, to reduce the corruption crimes, Hong Kong has formed a committee to combat corruption, and provided this committee with a huge budget of millions of dollars. More than 1000 employees work in this committee whose main task is to monitor corruption and eliminate it, in all its forms.

Apart from Singapore and Hong Kong, State of Chile is considered one of the countries that lived through very high rates of corruption, but today its situation has improved and it has fought corruption by simplifying procedures, rules and regulations, and has announced the applica- tion of the principle of transparency in all government institutions, its rank is (25/180) whereas its corruption perception score is $(67 / 100)$. The researcher strongly believes that a commitment to public office ethics reduces corruption, this statement is based on that, the ethics involve integrity, transparency, trust, and law respecting.

\section{CONCLUSION}

This article was written in order understand how a commitment to the public office ethics reduces the manifestations of corruption in Sudan government institutions. It has argued that adherent to public codes of conduct decrease the manifestations of corruption which are represent in; nepotism, embezzlement, harassment, bribery and forgery. Respecting the ethics such as; serving the public respecting the law, self-integrity, transparency, professional excellence are leads to the reduction of corruption phenomena in institutions. The writer, recommend strongly for the Sudan's public offices to adopt and practice the ethics of the people's institutions in order to be transferred to the coming generations.

\section{ACKNOWLEDGEMENT}

Thank you to all colleagues who helped complete the research and writing of this article. In particular, this work was supported by Master of Government Affair and Administration, Postgraduate Program, Universitas Muhammadiyah Yogyakarta.

\section{REFERENCES}

Abdullah, A., Sulong, Z., \& Said, R. M. (2014). An analysis on ethical climate and ethical judgment among public sector employees in Malaysia. Journal of Applied Business and Economics, 16 (2), 133-142. 
Available Online at https://journal.unismuh.ac.id/index.php/otoritas

Otoritas : Jurnal Ilmu Pemerintahan, 11 (1), April 2021, 61

Calderón-Orellana, M., \& Araya-Bugueño, R. (2019). The Codes of Ethics in Public Sector and the Incorporation of Values that Promote Open Government: The Chilean case. eJournal of eDemocracy \& Open Government, 11 (2).

Chapman, R. A. (2003). Ethics and Accountability in Public service. Teaching Public Administration, 23(1), 1526.

Chapman, C. R. A. (2019). Ethics in public service. Edinburgh: Edinburgh University Press.

Duraku, A. (2018). Ethics in Public Administration in Kosovo. European Journal of Multidisciplinary Studies, 3(4), 163169.

Elamin, N. (2019). A theoretical analysis of corruption in Sudan: Causes, diagnostics, consequences, and remedies. African Journal of Political Science and International Relations, 13(2), 416.

Ferreira, F. A., Castro, C., \& Lopes, C. (2019). Does corruption in the public sector reduce corporate ethics? - A panel data analysis. AIP Conference Proceedings, 2186(December), 1-5. https://doi.org/10.1063/1.5138000

Heckler, N., \& Ronquillo, J. C. (2020). Effective Resolution of Ethical Dilemmas in Social Enterprise Organizations: A Moral Philosophy and Public Management Approach. Public Integrity, 22(1), 39-53. https:// doi.org/10.1080/10999922.2018.14 77405

Hope, K. R. (2020). Corruption Reduction as a Target of the Sustainable Development Goals: Applying Indicators and Policy Frameworks. The Emerald Handbook of Crime, Justice and Sus- tainable Development, 105-130. https://doi.org/10.1108/978-178769-355-520201009

Ismail, A. (2017). Corruption in Sudan costs \$ 18 billion annually. Alaraby.Co.Uk.

Ismail, 0. (2011). The Failure of Education in Combating Corruption in Sudan: The Impact on Sustainable Development. OIDA International Journal of Sustainable Development, 2(11), 4350.

Kafi, M. Y. (2018). Reform and Administrative Development: between theory and implementation. Dimeshg- Seria: Raslan institution for publication and printation.

Martini, M. (2012). Corruption and anticorruption in Sudan. Berlin: Transparency International.

Osmani, S. E., \& Bashi, S. E. (2014). Ethics in public administration. ILIRIA international review, 4(1), 201-215.

Pertiwi, K., \& Ainsworth, S. (2021). "Democracy is the Cure?": Evolving Constructions of Corruption in Indonesia 1994-2014. Journal of Business Ethics, 173(3), 507-523.

Quah, J. S. (2017). Five success stories in combating corruption: lessons for policy makers. Asian Education and Development Studies, 6(3).

Saban, D., Basalamah, S., Gani, A., \& Rahman, Z. (2020). Impact of Islamic work ethics, competencies, compensation, work culture on job satisfaction and employee performance: the case of four star hotels. European Journal of Business and Management Research, 5(1). 
Available Online at https://journal.unismuh.ac.id/index.php/otoritas

Otoritas : Jurnal Ilmu Pemerintahan, 11 (1), April 2021, 62

Taboli, H. R., Samie'e Darooneh, M., \& Ehsani, A. (2019). Administrative Corruption: Why and How?. International Journal of Advanced Studies in Humanities and Social Science, 8(3), 282-288.

Yusuph, M. L., Guohua, W., \& Abeid, A. R.
(2016). Code of ethics and conducts in public service: The litmus test for public administrators ethical decision making in resolving ethical dilemmas: A comparative study of Tanzania and South Africa. IOSR Journal of Business and Management (IOSRJBM), 18(2), 79-87. 